Araștırma Makalesi- Gönderim Tarihi: 9 Eylül 2019 - Kabul Tarihi: 28 Aralık 2019

\title{
Christopher Nolan Sinemasında Klasik Anlatı Tekniklerinin Kullanımı: Inception Filmi Örneği
}

\author{
ÖZCAN DEMIR'
}

öz

Klasik anlatı sineması, terimi kökenini Aristoteles'in Poetika isimli eserinden alan anlatıya dayalı sinema biçimidir. Yapısal olarak serim, düğüm, çatışma, doruk nokta ve çözüm aşamalarından oluşmaktadır. Olay örgüsü ve neden-sonuç ilişkileri anlatı oluşturulmasında kullanılan temel ilkelerdir. Öykülerde gerçeklik kaygısı bulunmamaktadır. Ancak, gerçekçi öykülerle izleyicinin yapımı izlemeyi sürdürmesi amaçlanmaktadır. Sinemanın endüstriyel bakışına bağlamında izleyicinin ilginç olarak algılayacağı bir anlatının, teknolojik ve sinematografik olarak desteklenerek sunulması hedeflenmektedir. Klasik anlatı dalında eser veren yönetmenler, özellikle Hollywood sisteminde temel biçimsel özellikleri korumaktadırlar. Christopher Nolan, edebiyat öğrenimi görmüş bir yönetmen olarak filmlerinin önemli bir bölümünün senaryosunu da yazmıştır. Filmleri özgün ve yenilikçi olarak nitelenmektedir. Zamanın göreliliği ve gerçekliğin subjektifliği temalarını sıklıkla işlemektedir. Bu çalışmada, özgün sinema ve kurgu anlayışı ile Christopher Nolan'ın edebiyat bilgisinin de katkısıyla klasik anlatı geleneğini devam ettirdiği varsayılmıştır. Araştırmanın niteliksel tasarımı bağlamında, klasik anlatı tekniğine ilişkin temel literatür bilgileri aktarılmış ve Inception (Başlangıç, 2010) filminin klasik anlatı prensipleri bağlamında anlatı çözümlemesi yapılmıştır. Başlangıç filminin analizinde Todorov'un Aristoteles'in yapı anlayışı bağlamında geliştirdiği unsurlar ve Gerard Gennette'nin anlatı ve söylem bağlamındaki ilkeleri kullanılmıştır. Analiz sonucunda, Christopher Nolan'ın Başlangıç filminde, eserlerinin genelinde görüldüğü üzere edebiyat tekniklerini yorumladığı, psikoloji ve fizik alanındaki soyut kavramları görselleștirdiği görülmüştür. Filmin, temasında görülen zamanın göreliliği ve bilinçaltı gibi kavramların görselleştirilmesinde klasik anlatı sinemasının teknik ve anlatı düzeyindeki özelliklerinin kullanıldığı görülmüştür. Yönetmenin filminde kuvvetli nedensellik bağları dikkat çekicidir. Başlangıç filminin anlatı ve söylem bağlamında yönetmenin diğer filmleriyle ortak nitelikler taşıdığı ve yönetmenin klasik anlatı geleneğini sürdürdüğü sonucuna varılmıştır.

Anahtar Sözcükler: Sinema, Tür, Klasik Anlatı, Hollywood, Christopher Nolan

Atıf: Demir, 0̈. (2019). “Christopher Nolan Sinemasında Klasik Anlatı Tekniklerinin Kullanımı: Inception Filmi Örneği”. Akdeniz Üniversitesi Iletișim Fakültesi Dergisi, (AKiL) Aralık (32), s. 568-588

1 Dr.Öğr.Üyesi, Gaziantep Üniversitesi, Güzel Sanatlar Fakültesi Sinema ve Televizyon Bölümü ozcandemir@gantep.edu.tr ORCID NO: 0000-0001-9273-7672 


\title{
The Use of Classical Narrative Techniques in Christopher Nolan Cinema: The Example of Inception
}

\begin{abstract}
Classical narrative cinema is a term used for the narrative form of cinema originating from Aristotle's Poetics. Structurally, it consists of exposition, development, complication and climax and resolution stages. The plot, cause and effect relationships are the basic principles forming narrative. It is aimed to present a narrative that will be perceived as interesting by the audience in the context of the industrial perspective of cinema with technological and cinematographic support. The directors, who use classical narrative, maintain the basic formal features, especially that of Hollywood system.Christopher Nolan, as a literary director, wrote the scenery for a significant portion of the films he directed. His films are described as unique and innovative. He often uses the relativity of time and the subjectivity of reality themes. In this study, it's assumed that Christopher Nolan sustains classical narrative tradition by the contribution of his literary knowledge with his original cinema and editing understanding. According to the qualitative nature of the study, basic literature information about classical narrative technique was given and narrative analysis of Inception (2010) movie was made. The text of the director's film "Inception" (2010) was analyzed according to the classical narrative style by using the narrative analysis method. In the analyzing process, Todorov's elements according to Aristotle's understanding of structure and Gerard Gennette's principles of narrative and discourse were used. As a result of the analysis of the movie Inception, it is concluded that Christopher Nolan interprets literary techniques and visualizes abstract concepts in the field of psychology and physics, as seen throughout his work. It was observed that in the visualization of concepts such as the relativity of time and the subconscious classical narrative cinema techniques were used. In the director's film, the strong causality between events is remarkable. Christopher Nolan's film "Inception", has got common features with his other films in terms of narrative and discourse and that the director continues the classical narrative tradition.
\end{abstract}

Keywords: Cinema, Genre, Classical Narrative, Hollywood, Christopher Nolan

\section{Giriș}

Modern öykü anlatıcısı olarak sinema, bir olaylar dizisinin sinematografik ilkelerin kullanımı yoluyla izleyiciye nakledilmesini sağlamaktadır. Sinema izleyicisinin ilgiyle takip ettiği, filmin izleyicinin izafiyet çerçevesine göre alımlanmasını sağlayan bağlam ise anlatıdır. Sinema anlatısının "belirli bir zaman ve uzamda meydana gelen sebepsonuç ilişkisi ile bağlanmış olaylar zinciri" olduğunu söylemek mümkündür (Bordwell ve Thompson, 2008: s.75)."

Anlatı teriminin tanımını öykü ile karıştırmamak gereklidir. Klasik anlatıyı oluşturan dramatik olay, belirli türde çelişkilerin sonucunda ortaya çıkan ve eyleme sevk eden zorunluluklar içeren bir öğedir. Dramatik olaylarda, belirli bir evreden itibaren olayların evrimi hız kazanır ve kendi kendine hareket ediyormuş gibi görünür (Ünal, 2015: s.82). Filmi oluşturan olaylar zinciri bir öykü meydana getirmektedir. Öykülerin en önemli özelliği ise olay örgüsüne sahip olmalarıdır. Daha genel bir bakış açısıyla, öykü, diğer 
kurmaca olan ve olmayan edebi ürünlerle birlikte anlatıdır (Ersümer, 2013: s.19). Anılar ve bilimsel eserler gibi edebiyat ürünlerini bu grupta değerlendirmek mümkündür.

Öykünün bir başlangıcı ve sonu vardır. Film öyküsüyle, gerçek hayatın dışında bir olay izleği oluşturulmaktadır (Metz, 2012: s.31-32). Ancak, olayların rastlantısal olarak sıralanması öykü oluşturmak için yeterli değildir. Olaylar arasında bir neden-sonuç ilişkisi kurulmalıdır. Bordwell ve Thompson'a göre; izleyicinin anlatıyla bağ kurması, değişim-denge, sebep-sonuç ve zaman-uzam modellerini kavramasıyla mümkündür ve tüm bu faktörler arasında merkezi öneme sahip olanlar nedensellik ve zamandır (Bordwell ve Thompson, 2008: s.75).

Öyküyü oluşturan olaylar arasında nedensellik ilişkisi kurmadan onları sıralamak anlaşılırlık açısından mümkün değildir. Nedensellik ilişkisi, beraberinde uzamı oluşturacaktır. Nedensellik ve uzam bağlarının kurulması olaylara ilişkin zaman bağının da kurulmasını sağlayacaktır. "Bir öykü iki kez zamansaldır. Bunlar anlatılan şeyin zamanı ve öykünün zamanı ya da diğer bir ifade ile gösterenin ve gösterilenin zamanıdır (aktaran Ulutaş, 2017: s. 129)."

Sinema sanatında klasik anlatının tanımlanmasında kullanılan "nedensellik" ve "olay örgüsü kavramları"nın kökleri Aristoteles'in Poetika'sına uzanmaktadır. Aristoteles'e göre anlatı, "tamamlanmış, bütünlüğü olan bir eylemin taklididir, bu eylemin belli bir bütünlüğü (uzunluğu) vardır. Çünkü, (aslında) hiçbir büyüklüğü olmayan bütün’ler de vardır. Bir bütün ise, başı, ortası ve sonu olan şeydir (Aristoteles, 1987: s.27)." Aristoteles'in tanımı anlatı-gerçek ilişkisine vurgu yapmaktadır. Anlatı, gerçek eylemin bütünsel bir taklididir. Gerçek hayatın aksine, kesin bir başlangıcı, ortası ve sonu vardır. Anlatı sineması için de aynı özelliklerden bahsetmek mümkündür. Klasik anlatı filmi gerçeği anlatma iddiasında olduğu için tüm mizansen öğeleriyle gerçek hayatı taklit etme çabasındadır. Kendi gerçekliğini inşa eder. Anlatıya sahne olan dramatik uzam, gerçeğin yoğunlaştırılmış ve yeniden yazılmış halidir. "Bir öyküde gerçekliğin ve duygulamın asli yaratıcısı karakter eylemleridir. Ancak bu eylemlerin geçtikleri mekanlar ve onların yapısal özellikleri de en az eylemler kadar etkili bir söylem oluşturmaktadır (Ulutaş, 2017: s.151)." Dramatik uzamda anlatılmak istenen olay açısından gerçeğin bir anlam taşıyan parçalarına yer verilmekte ve bu parçalar, diğer parçaları etkileyebilecek ve denetleyebilecek şekilde düzenlenmektedir (Foss, 2016: s.163). Filmin, başlangıcı, ortası ve sonu vardır. Buradaki kasıt filmin kesin ya da belirsiz bir sonla bitip bitmediği değildir. İzleyici biçimsel olarak da öykünün bittiğini rahatlıkla anlayabilir.

Anlatılar, insana dair çalışmaların önemli bileşenleridir. Doğa bilimleri, beşerî ve sosyal bilimler açısından inceleme konusudurlar. Anlatı çalışmaları yazılı edebiyata ve sinemayı da içeren farklı medya ortamları üzerinden anlatılabilecek öykülere odaklanmıştır. Sinema filmleri tarihsel olarak edebi kaynaklara dayandığından, edebi anlatı bilimi film anlatısı üzerine yapılan çalışmalar üzerinde etkili olmuştur (Larsson, 2014). Edebi alanda kullanılan bazı anlatı inceleme yöntemleri sinema için de kullanılmıştır. "Anlatı kuramcısı Tzvetan Todorov'un Aristotleles'in yapı anlayışına dayandırdığı yöntemine göre anlatıları açıklamak için kullanılan üç aşama;

- Denge durumu

- Dengenin bir olay nedeniyle bozulması 
- Dengenin yeniden sağlanmasına yönelik başarılı çabadır.

Bir aşamadan diğerine geçiş anlatının 'dönüm noktası' olarak adlandırılır (Buckland, 2018: s.52)."

Todorov, karakterlerin belirlediği aşamalar ile etkileşimini vurgulamak için bunları genişletir;

- "Denge kurulur

- Denge bozulur

- Karakterler dengenin bozulduğunu tespit ederler

- Karakterler dengeyi yeniden sağlamak için sorunu ortadan kaldırmaya çalışırlar

- Denge eski haline getirilir (Edgar-Hunt vd, 2012: s.52)."

Todorov'un dönüm noktalarıyla bölünen üç parçalı yapısı bakımından anlatıları incelerken, anlatının doğrusal bir yapı olarak değil dairesel bir yapı olarak tanımlandığına dikkat etmek önemlidir (Buckland, 2018: s.53).

Sinema anlatısının açıklanmasında anlatısal aşamalar bağlamında zaman-uzam ilişkisinin farklı biçimlerde yorumlanması mümkündür. Christopher Nolan, klasik anlatı ürünü filmlerinde zaman algısını elde ettiği görüntülerle, sesle ve kurgu temposuna etki eden çapraz kesmeleriyle oluşturan bir yönetmendir. Bu haliyle Nolan'ın, 'dönüm noktaları'ndaki geçişleri kendi özgün biçemiyle gerçekleştirdiğini söylemek mümkündür.

Following (Takip, 1998), Memento (Akıl Defteri, 2000), Insomnia (Uykusuz, 2002), The Prestige (Prestij, 2006), Inception (Başlangıç, 2010) ve Interstellar (Yıldızlararası, 2014) gibi filmlerinde anlatı sinemasının zaman kalıplarını öyküsünü derinleştirmek için yeniden biçimlendirmiştir.

\section{Amaç ve Yöntem}

Çalışmanın temel varsayımı; Christopher Nolan'ın özgün içerikte ürettiği yapımlarını oluştururken klasik anlatı tekniklerini kullandığıdır. Yönetmenin anlatı itibariyle özgün yapıtlarından birisi olarak görülen filmlerinden Başlangıç'ın analiz için seçilmesi, klasik anlatı kalıplarıyla yenilikçi bir kurguya ulaşmanın örneklerinden birisi olarak değerlendirilmesinden kaynaklanmıştır.

Klasik anlatı tekniğine ilişkin temel literatür bilgilerinin aktarılması ve filmin bu tekniklerin kullanımı açısından çözümlenmesi çalışmanın niteliksel tasarımından kaynaklanmıştır. "Niteliksel incelemede analiz, gözlemlerle (örneğin ilgili kayıtlı literatürden, mülakatlardan, alan gözleminden) elde edilen verilerin ayıklanması, düzenlenmesi, anlamlı parçalara ayrılması ve bu parçaların içlerinin anlamlı bir bütün oluşturacak biçimde doldurulması gerektirir (Erdoğan, 2003: s. 261)." Nolan'ın oluşturduğu anlatıların temel özelliklerinin tespit edilmesi amacıyla anlatı çözümlemesi tekniği kullanılmıştır. Bu teknik yardımıyla; "anlatıcıların aktardıkları olaylara düzen kazandırma yöntemleri, dinleyiciler üstünde çok yönlü etki bırakmak amacıyla dilsel ve kültürel öğelerin 
bireylere ve kültürlere özgü kullanımı, anlatıcının duygu, düşünce ve tepkilerinin anlatı örüntüsü içine yerleştirilmesi ve dinleyici ile anlatıcı arasındaki etkileşimin değerlendirilmesi mümkündür (Yemenici, 1995: s.39)." Anlatı çözümlemesi, özellikle sinema gibi çok katmanlı bir sanat dalında anlatının tüm boyutlarıyla çözümlenmesi için kullanılabilmektedir.

$\mathrm{Bu}$ yöntemle biçimsel boyut yanında, filmin yönetmeni tarafından oluşturulma sürecine de vurgu yapılması mümkündür. "Anlatı çözümlemesi çeşitli yöntemler doğrultusunda yapılabilir. Biçembilim incelemeleri, göstergebilimsel çözümlemeler, söylem çözümlemesi ya da söz konusu yöntemlerin birlikte kullanılması anlatının yüzey yapısından derin yapısına ulaşma çabalarıdır (Özkan ve Gündoğdu, 2012: s.2)." "Anlatı çözümlemesinde artık sadece yüzey yapıda ortaya çıkan öğeler değil, anlatıcının söylemleme süreci, dinleyen ile etkileşimi ve bunun söylemlemeye etkisi ve dinleyenin anlama süreci gibi konular üzerinde de durulmaktadır (Zeyrek, 1991: s.108)." Nolan'ın özgün biçimini ve kurgusunu oluştururken klasik anlatı sinemasının kabullerini kullanma biçiminin anlatı çözümlemesi yöntemiyle açığa çıkarılması amaçlanmıştır.

Bu çalışmada, öncelikle anlatı sineması ve anlatının oluşturulmasına etki eden faktörler ele alınmıştır. Anlatı sinemasının nedensellik, uzam ve zaman boyutlarıyla incelenmesinin ardından; Christopher Nolan'ın kullandığı klasik sinema anlatısında zamanın önemi ve kullanım biçiminin tespiti amacıyla; Başlangıç filmi Todorov'un anlatı için belirlediği beş ana aşama bağlamında çözümlenmiştir.

Çalışmaya konu olan Inception (Başlangıç, 2010) filmi, Nolan'ın rüya içinde rüya olarak betimlediği ve ayna metaforuyla anlattığı "mise en abyme" kavramı ile sinemasal zamanı yeniden yorumladığı bir yapımdır. Gerçeklik ve zaman olgusu ile ilgili söylemiyle dikkat çekicidir. Bu nedenle, Başlangıç (2010) filminin çözümlenmesinde Gerard Genette'nin Anlatının Söylemi: Yöntem hakkında bir deneme isimli eserinde belirttiği anlatı söylem ilişkisinin analizine dayalı önerisi bağlamında değerlendirme yapılacaktır (aktaran Edgar-Hunt vd, 2012: s.54). Todorov'un anlatı çözümlemesi için önerdiği aşamaların filmde tespitinin ardından, Nolan'ın anlatısındaki temel kavramlara odaklanılabilmesi amacıyla teknik düzeyde mizansene bağlı sinematografik öğelerin de söylem üzerine etkilerinin değerlendirilebilmesi için Genette'nin önerdiği;

“Hikâye (içerik)

Olaylar

Karakterler

Ortam

\section{Anlatım (söyleme)}

Tipler

Düzeyler

Ses

\section{Metin (sunum)}

Zaman

Karakterizasyon kronoloji/nedensellik

eylemler/etkileşimler

zaman mekânsal bileşikler

güvenilir/güvenilmez

iliştirilmiş anlatım

anlatıcı/karakter

düzen/süre/sıklık

kişilik özellikleri/nitelikler 
Odaklanma olayları kim görüyor/algılıyor/yargılıyor" başlıkları bağlamında çözümleme yapılmıştır (Edgar-Hunt vd, 2012: s.54).

Çalışmanın amacı; filmin teknik ve mizansen öğelerinin de katıldığı çözümleme ile Nolan'ın filmlerine hâkim olan gerçekliğin göreliliği fikrini anlatı öğeleri olan zaman ve uzam algısıyla nasıl anlattığının belirlenmesidir.

\section{Film Anlatısı}

Aristotoeles'in Poetikası'na dayalı gelişen anlatı kavramının temel özelliklerinin sinema sanatının ürünleri olan filmlerin üretilmesinde etkili olmuştur. Makal'a göre; "sinema gelişim sürecinde gerçeğin değil, teatral görüntüyü sunan Méliès'in kurmacalarının yolunu seçmiş, öykü anlatmanın, mitler, fantazyalar, düşler yaratmanın bir aracı olmuştur (Makal, 2009: s. 138)." Yönetmenler, filmlerini ilginç hale getirmek, izleyici üzerindeki hayret ve şaşkınlık gibi etkileri kontrol edebilmek adına anlatılarını farklı biçimlerde şekillendirmiştir.

Sinemada öykü anlatmada Klasik Hollywood Sineması, 1920’lerin Sovyet Sineması, 1960’ların Yeni Dalga Filmleri ve Amerikan bağımsız sineması gibi biçimlerden söz etmek mümkündür (Ersümer, 2013: s.185). Sinema filmi yapmak için, kurmaca olan ve olmayan anlatılar geliştirilebilir. Kurmaca film anlatısı oluşturmada kalıplaşmış hâkim gelenek "Klasik Hollywood Sineması" olarak isimlendirilmektedir. Uzun, istikrarlı ve çevresini etkileyen bir geleneğe sahip olan bu biçim en detaylı örneklerini Hollywood stüdyolar sisteminde vermiştir (Bordwell ve Thompson, 2008: s.94).

Klasik anlatı sinemasını diğer anlatı yöntemlerinden ayıran birtakım özelliklerden bahsetmek mümkündür. Milattan önce dördüncü yüzyılda Platon ve Aristo sinemada anlatı oluşturma açısından önemli olan mimemis ve diegesis ayrımlarını yapmışlardır. Mimesis kavramı, bir olayın ya da hareketin anlatıcı olmadan taklit yoluyla anlatımı; diegesis ise bir öyküyü anlatıcı aracılığıyla anlatmaktır (Larsson, 2014). Klasik anlatı sinemasının mimesis yönteminden yararlandığını söylemek mümkündür.

Hollywood Sineması, temelde izleyicide gerçekçilik etkisi uyandıran bir taklit mekanizmasını mimesis kavramı çerçevesinde geliştirmiştir. Monaco'ya göre; “Hollywood otuzlu yılların ortasında, Altın Çağ'ın genellikle üst düzeyde beğenilen, sık sık aldatıcı, fantazi 'eğlence değerlerinin' emrinde olan bir film yapımı tarzı içine girdi (aktaran Makal, 2014: s. 42)." Klasik anlatının tarihlendirmesini yaparken bahsedilen hedeflerinin gözönünde bulundurulması gereklidir. Sinema, teknik olarak 1895 yılında Lumiere kardeşler ile başlatılsa da anlatı sinemasının gelişmesi için 1910'lu yıllara kadar beklemek gerekiyordu. Bu dönemde, dünya ölçeğinde üretilen filmlerin önemli bir bölümünün film düzenleme mekaniği, kurgu, mizansen ve kamera kompozisyonu teknikleri açısından David Wark Griffith'ten esinlendiğini söylemek mümkündür (Meritt, 2011). O'nun sinema açısından önemi kendisinden önce keşfedilen teknikleri dramatik bir yolla kullanmasıdır. "Griffith sinemasal birimin tiyatrodaki gibi sahneler olmayıp tek tek çekimler olduğu temel bilincine sahipti (Armes, 2019: s. 109)." "Griffith sinemaya başladığında, kurgu sözdizimi keşfedilmişti. Klasik anlatı için önemli olan montajın kullanılma amacının, duyuların veya anlamların yaratımı olduğu ve bunun görüntülerin birleştirilmesiyle elde edildiği biliniyordu (Bazin, 2011: s.34). Kuleshov’un Mozhukhin 
çekimi (1918) ile sinemada anlamın, görüntülerin içeriği yerine onları bir araya getiren kurgunun biçimiyle belirlendiği ispatlanmıştı (Toscano, 2015). Ancak, Griffith klasik kesme (classical cutting) ile öncüllerinin icat ettiği birçok tekniği ilerletti ve sanatsal hale getirdi. The Birth of a Nation (Bir Ulusun Doğuşu-1915)'da kullandığı klasik kesme ile kurgu yardımıyla düşünceleri birleştirmeyi başardı (Gianetti, 2001: s.138)."

Klasik Hollywood sinemasının sessiz film döneminde, başlamasının ardından; uzun metraj sinema filmlerinin üretimine hız verilen Birinci Dünya Savaşı sonrası dönemde, sesli filmlerle devam eden bir süreçten söz etmek mümkündür. "Klasik Hollywood" sinemasının teknik düzeyde 'ses'li olan dönemini 1930 ve 1960 yılları arasında tarihlendirmek mümkündür. Hollywood, klasik anlatıda sesi gerçekliğin taklidinde önemli bir araç olarak kullanmıştır (Neumeyer, 2011).

Klasik anlatı sinemasının tarihsel, teknik ve estetik boyutlarla değerlendirilmesi mümkündür. Ekonomik anlamda bir iş alanı olarak görüldüğünden izleyici açısından değer ifade eden, ona ilginç gelen içeriklerin üretilmesi, teknolojik gelişmelerin bu ilgiyi sürdürmek için kullanılması Hollywood'un hedefleri arasında olmuştur.

Bu durum, sanatın asıl görevi konusunda yapılan tartışmalarda sıklıkla eleştirilmiştir. Bertold Brecht gibi isimler, Hollywood'u bir 'yalan pazarı' olarak görmüştür. Makal'ın belirttiği üzere; "sinemanın ticari yönünü göz ardı eden Brecht'e göre; "sinema Aristocu olmayan bir dram sanatının (yani özdeşleşme görüngüsüne, mimesise, öykünmeye dayanmayan bir dram sanatının) ilkelerini olduğu gibi kabul edebilir"di (Makal, 2014: s. 375). Sinemanın endüstriyel bakışında ise izleyicinin ilginç olarak algılayacağı bir anlatının, teknolojik ve sinematografik olarak desteklenerek sunulması hedeflenmiştir. 1960'lı yıllara kadar süren Klasik Hollywood geleneğinin tüm bu faktörlerden etkilenen yapısı konusunda David Bordwell ve Kristin Thompson'un tespitleri önemlidir. Bordwell ve Thompson'a göre;

Gerçeklik izlenimi oluşturulması çabası yanında klasik anlatının bir diğer dayanağı da karakterlerdir. Karakter, engelleyicisi ile mücadele eder ve isteklerinin etkisiyle dramatik yapının ilerlemesini sağlar. Klasik anlatının dramatik yapısı değişim üzerine kurgulanmıştır. Anlatıda olay örgüsü içerisinde yalnızca sebep-sonuç ilişkisi bağlamında önemli olanlar film metnine dahil edilir. Neden-sonuç ilișkisinin etkili biçimde sunulabilmesi için olaylar dizisi kronolojisi düzenlenir. Yönetmenin, anlatıda zamanı düzenlemek için çeșitli araçları bulunur. Randevu (appointment); karakterlerin belirli bir zamanda karşılaşmasını sağlar. Son tarih (deadline); olay örgüsünü sebep-sonuç ilişkisine bağlar. Hollywood anlatı sineması, nesnel bir öykü gerçekliği sunar. Böylece izleyici nesnel olmayan unsurların farkına varabilir. Klasik anlatı sinemasında izleyicinin sadece karakterin gördüklerine ilişkin bilgiye değil; karakterin ulaşmasının mümkün olmadığı bilgiye de ulaşması mümkündür. Ayrıca, olay örgüsünü daha şaşırtıcı yapmak adına yönetmenler izleyiciye çözülmesini istedikleri bulmacalar ve bunlara ilişkin ipuçları sunabilir (Bordwell ve Thompson, 2008: s.94-96).

Hollywood anlatısında zaman ve uzam kullanımı birbiriyle bağlantılı olarak kurgu yardımıyla ilerlemektedir. Zamanın düzenlenmesi çekimler ve kurgu temposuyla yapılabilmektedir. Çoğu klasik sinemacı, aksiyonu birkaç farklı açıdan görüntülemekte böylece zamanı ve uzamı başlangıcından sonuna kadar sıkıştırabilmektedir (Gianetti, 2001: s.101). Kurgu, film anlatısında değişik faktörleri etkileyen teknik bir araçtır. Yönetmenin filme yaklaşımını yansıtmasını sağlamaktadır. Görüntülerin öncesinde 
ya da sonrasında hangi görüntülerin geldiği, görüntünün perdede kalma süresi, ses ve müzik kullanımı filmin anlamını belirleyebilmekte ya da değiştirebilmektedir (Ünal, 2015: s.17).

Klasik anlatı sinemasında perdede izlenen olayların oluşumu ve geliştirilmesi kurgusal yöntemlerle gerçekleştirilmektedir. Bu yöntemler, sinema yönetmenine gerçek zaman ve mekân unsurlarını yeniden biçimlendirme olanağı vermekte; filmin anlatım gücünün geliştirilmesini sağlamaktadır (Mükerrem, 2012: s.29).

Klasik anlatıda devamlılık kurgusu teknikleri sahneyi birden çok çekime bölen ve bu parçalardan sentetik bir uzam ve zaman birliği yaratmayı amaçlayan tutarlılık ve oryantasyon odaklı tekniktir (Buckland, 2018, s. 29). "Devamlılık temelde gerçekmiş görünümü sağlayabilmeleri için öyküde, konuşmalarda ve görüntüde tutarlılık demektir (Brown, 2014: s.78)." "Klasik anlatı filmlerinde kesmeler görünmezdir ve görüntüler devamlılık içinde akıyormuş duygusu verirler. Hareket, görüntü ve sesin gerekli olan illüzyonu yaratabilmesi için plandan plana kesmeler verili zaman dilimi içinde devamlılığı sağlamalıdır (Barnwell, 2015: s.172)." Klasik devamlılıkta, aktörlerin yönelimlerini ve göz çizgilerini bir eylem ekseni (ya da 180 derecelik çizgi) belirler ve çekimler açıları ne kadar farklı olurlarsa olsunlar bu eksenin bir tarafından gerçekleştirilir (Bordwell, 2016: s.216). Devamlılık kurgusunun amacı izleyicinin filmle özdeşleşmesini ve Aristotelesçi anlamda bir ruhsal boşalım (katharsis) yaşamasını sağlamaktır (Çakır, 2019: s.15).

Sinema anlatısında filmsel zaman senaryoya göre biçimlenmektedir. Yönetmenin filmsel zaman üzerinde kuvvetli bir kontrolünün bulunduğunu söylemek mümkündür. Sinemacı zamanı doğal akışıyla verebilir, hızlandırabilir, yavaşlatabilir, durdurabilir, zaman içinde atlamalar yapabilir, zamanı tersine döndürebilir ve uzam içinde atlamalar yapabilir. Yönetmen filmin süresi ve temposunu dikkate alarak "derişik zaman" ilkesiyle herhangi bir olgunun doğadaki gerçek süresine oranla kısaltılmasını sağlayabilir (Özön, 2008: s.164). Dramatik anlamda öykü anlatısı için hayati önemi olan bir sahnenin kurgu teknikleri yardımıyla uzatılması sinematografik bir intiyaç haline gelebilir. Filmsel zamanla gerçek zamanın birebir uyuştuğu zamandaşlık ise; gerçek zamanın gerilim unsuru olduğu sahneler klasik devamlılık çekimleriyle bölünmeden gerçekleştirilir. Sahnedeki kurgu oyuncuların hareketlerinden kaynaklanan kompozisyon değişimleri ve kamera hareketleriyle sağlanmaktadır (Ünal, 2015: s.160).

Sinemasal zamanın film temposuyla ilişkilendirilmesi aşamasında dramatik etkilerini de dikkate almak gereklidir. Anlatı sinemasında tempo belirli durumlara dikkat çekmek adına yeniden düzenlenebilir. Hız ve tempo göreli kavramlardır. Sinema filmi açısından düşünüldüğünde diğer sahnelere ya da diğer sahnelerin kurgu temposuna göre bir artış ya da azalıştan bahsetmek mümkündür. "Hız, sınırlama ve yavaş hareketin gücüyle dengelenmeden, salt olarak deneyimlenemez (Biro, 2011: s.48)."

Klasik anlatıda olayların sebep-sonuç ilişkisi içerisinde anlatımında kronolojisi dikkate alınmaktadır. Ancak, yönetmenin biçimsel istekleri ve senaryodan kaynaklanan gereksinimlerle kronolojinin sunumunda değişiklikler yapılabilmektedir. Yönetmenin olay örgüsünün sunumunda yaptığı deneysel değişiklikler her zaman klasik anlatı geleneğinden uzaklaştığı anlamına gelmemektedir. Christopher Nolan, Memento (Akıl Defteri-2000) filmindeki farkı biçimini subjektif bakış açılı renkli görüntüler ve 
objektif bakış açılı siyah beyaz flashbackler ile oluşturmuştur (Myers, 2017). Leonard Shelby'nin durumunu anlatan tekrar eden diyaloglar ve olaylarla izleyicinin amnezisi üzerinde odaklanmasını sağlamıştır. Oluşturduğu kurguda amnezi hastası birinin parçalı hafızasını anlatmıştır. Olay örgüsü hangi eylem akışının ileriye doğru aktığını açığa çıkararak öykünün ilerlemesini sağlamıştır (Bordwell, 2016: s.149)."

Anlatı sinemasının temel tekniklerinden paralel kurgu (cross cutting) ile filmsel zaman, uzam ve hız ile ilgili izlenimler oluşturmak mümkündür. Paralel kurgu ile farklı uzamlardaki aksiyonlar bağlanarak, izleyici zihninde olaylar arasında ilişki kurulması sağlanmaktadır. Griffith paralel kurgu ile iki farklı coğrafyadaki bağımsız hareketlerin çekimlerini birleştirerek eşzamanlılık etkisini sağlamıştır. Abel Gance, 'La Roue' (Tekerlek-1923) filminde sabit hızı bir lokomotifin hızının giderek arttığı izlenimini oluşturmuştur. Bunu azalan uzaklığın katlı çekimleri sayesinde yapmıştır (Bazin, 2011: s.33).

Film kurgusu yardımıyla uzam etkisi oluşturmak mümkündür. "Çevirim oyunluğunda (senaryosunda) yer alan çekimlerin, uygulayımsal zorunluluklarından dolayı değişik zamanlarda, değişik yerlerde çevrildiğini biliyoruz. Bunlar, kurgu yoluyla oyunluktaki sıralarına göre dizildiklerinde, hiç olmazsa aynı görünçlük, aynı ortam içinde, zaman ve yer bakımından birbirini izleyen bir bütün oluşturur (Özön, 2008: s.163)."

Klasik anlatı sinemasında dramatik olay örgüsünün ilerlemesini karakterler sağlamaktadır. Karakterler öykünün niteliğine göre onları toplumdaki diğer bireylerden ayıran fiziki/biyolojik, psikolojik, diğer kişilerle ilişkilere dair ve kültürel anlamda özelliklere sahip olmalıdır (Ersümer, 2013: s.87). "Kişilikler, kendilerine verilen nitelikler ve koşullarla uyumlu ve mantıklı şeyler yapmalıdır. Kişiliklerin, dramanın gidişini etkileyecek nitelikleri özenle çizilmelidir. En karmaşık kişilikler bile eksiksiz görülmelidir (Foss, 2016: s.137)." Senarist, karakterin özelliklerini filmin konusuna göre belirlemekte, hangi özelliklerin belirginleştirilmesi gerektiğine senaryosu bağlamında karar vermektedir. Karakterlere ilişkin kararların yönetmenler tarafından film yapım sürecinde gözden geçirilmesi mümkündür.

Klasik anlatıya kaynaklık eden temel öykü, filmlerde görülen ve yönetmenlerin yapımın özgünlüğünü sağlamak için farklı biçimlerde işleyebileceği kavramları içermektedir. Senaryoya taslak olan temel öyküde;

Öykünün yeri ve zamanı

Kimin öyküsü olduğu

Öyküyü başlatan çatışma

Olaylar dizisindeki önemli gelişmelerin kısa bir şekilde açıklanması

Doruk nokta ve çözüm bilgilerine yer verilmektedir (Miller, 2016: s.41).

Miller'ın tespit ettiği senaryo taslağında bulunması gereken bilgiler anlatının dramatik anlamda ilerlemesi için gereklidir. Klasik dramatik yapıda anlatı; serim, düğüm, çatışma, doruk nokta ve çözüm aşamalarını içerir. Serim bölümünde, hikâyenin karakterleri ve olaya sahne olan coğrafya tanıtılır. Hikâyenin başından sonuna kadar süre- 
bilen bir bilgilendirme sürecini kapsar (Ersümer, 2013: s.43).

Aristoteles tragedyanın aşamalarını anlatırken; "Çoğu yapıtın dışında, kimi yapııın da içinde bulunan olaylar, düğümü oluştururlar; bütün geri kalan olaylar ise, çözümü. Düğüm deyince, yapıtın başından mutluluk yahut felakete doğru baht dönüşü için sınır oluşturan bölüme dek uzanan olaylar örgüsünü anlıyorum. Çözüm deyince de, bu baht dönüşünden yapıtın sonuna dek olan bölümü anlıyorum (Aristoteles, 1987: s.51)."demiştir.

Öykünün geçtiği coğrafi bölge ve zaman aralığı ile ilgili bilgi filmde verildikten sonra sıra anlatının başlatılmasına gelmiştir. Klasik anlatıya da kaynaklık eden dramatik öğeler bağlamında çatışma öykünün başlamasını sağlamaktadır. Bu noktada, öykünün ana karakterinin kim olduğu ve istekleri hakkında bilgi verilmelidir. Ancak arzu eden kişinin arzusunu gerçekleştirmesi için sınırlı bir süresi olmalıdır. Karakter arzusunu gerçekleştiremediği takdirde felaket seviyesinde bir zarara uğramalıdır. Karakterin hedefe ulaşma dürtüsü kuvvetli ve hedefe ulaşılması güç olmalıdır. Böylece çatışma büyüyecektir (Foss, 2016: s.175).

Klasik anlatıda çatışmaların oluşturulması yanında bunların inandırıcı da olması gerekmektedir. Çatışma dramatik yapıyı hareketlendirmelidir. Karakteri yeni edimlere yöneltmelidir. Çatışmanın çözümü film boyunca oluşan geriye dönük tüm çelişkileri de izleyicinin kafasında soru işareti kalmayacak biçimde çözmelidir (Ünal, 2015: s.82).

Klasik anlatıda, dramatik hareket ve gelişme içinde yeri olmayan herşey dışarıda bırakılmalıdır. Dramanın araçlarının çerçeveye yerleştirilmesine, cisimlere, tavırlara, kişisel niteliklere vb. dramatik önem vermeye ya da kazandırmaya düğümleme denilmektedir. Daha sonra bu düğümler doruk noktasında çözülecektir (Foss, 2016: s.180).

Klasik anlatı sinemasıyla ilgili olarak dikkat çekilmesi gereken bir diğer kavram da anlam oluşturma süreçleri ve yönetmenin buna katkısıdır. Senaryo ve sinematografi anlatının izleyiciye ulaşmasını sağlamaktadır. Sinemada anlam yaratma bağlamında, öykünün izleyicinin ilgisini çekmesi ve izlenmesi için anlamlı olması gereklidir. Anlam kültürel kodlardan, metinsel dizgelerden ve çıkarsamalardan oluşmaktadır. Kaynağı, sinemanın dil yapısıdır. Yönetmenler anlatılarını izleyiciye ulaştırmak için sinema dili bağlamında gelenekten yararlansalar da geleneği aşabilir ve değişik anlatımlar oluşturabilirler (Büker, 2011: s.122).

\section{Bir Anlatı Geliștirme Biçimi Olarak Mise en Abyme}

Sinema anlatısında kullanılan kavramlardan mise en abyme (mise en abime) Andre Gide, Claude Magny ve Lucien Dallenbach gibi düşünürlerin çalışmalarıyla ortaya çıkmıştır. Andre Gide, 1893 yılında "mise en abyme" kavramını parça bütün ilişkisiyle açıklamıştır. Bir eserin özelliklerini taşıyan parçalarının, bu eserin tamamını yansıttığı fikrini savunmuştur. Birleşerek eseri meydana getiren pek çok parçanın yine de farklı kaldıkları düşüncesine vurgu yapmıştır (Snow, 2016: s.10). 
Kökleri edebiyatta bulunan mise en abyme kavramı modernist yazarların yaptıkları işin her aşamasında kendilerinin ve hareketlerinin bilincinde oldukları eserlerinin bir okuyucusu ve eleştirmeni oldukları görüşüne dayanmaktadır. Benzer görüntülerin veya olayların yinelenmesinin yanı sıra kıyas yoluyla çoğaltmayı da kapsamaktadır (Lawlor, 1985: s.829).

Eleştirmen Claude Magny, 1950'de Gide'nin 'Sahteciler' isimli romanı ile ilgili semiyolojik bir yorum yapmıştır. Gide'nin bir süper roman yazmakta olduğunu iddia etmiştir. Çünkü 'Sahteciler' romanında 'Sahteciler' isminde bir roman yazılmaktadır. Romanın içinde yazılan roman ile parça bütün ilişkisi bulunmaktadır. Bu nedenle, bağlantılarının, matematiksel olarak değerlendirilebilecek "yansıma"ya benzer bir süreç olduğu sonucuna varmıştır. Magny'nin "yansıma" görüşü, yansıtma ile karşılaştırılarak ele alınmıştır. Magny basamaklı bir ayna metaforu önermiştir. Yansımalar gizem ve derinlik illüzyonu oluşturmaktadır. Oluşan derinlik illüzyonu yansımaların sonsuz bir uçurumudur (abyss). Magny oluşan etkiyi "mise en abyme" olarak adlandırmıştır (Snow, 2016: s.10-11).

Aynalama, tekrarlama ve simetri, klasik sinemanın ana yapısal kaynaklarıdır, ancak, genellikle derin yapıya gömülüdür veya birbirlerinin yerine geçen veya sureti olarak rol oynayan karakterler tarafından gizlenir (Elsaesser, 2018: s.23).

Eleştirmen Lucien Dällenbach, 1977'de Magny'nin açıklamasını incelemiş ve kabul etmiştir. Gide'nin fikrini 'metnin ulaşılmaz kalbi' olarak nitelemiştir Magny'ye göre metindeki bağlantılar dönüşlü ve sonsuz defa tekrarlanabilir niteliktedir. Dällenbach, Gide'nin parça bütün ilişkisini edebi alanda bir ayna metaforuna benzetmiştir. (Snow, 2016: s.11). Bununla birlikte, Lucien Dallenbach konuyla ilgili kitabına koyduğu gibi, "mise en abyme", anlatı kronolojisinin "mise en nedeni" olarak hareket eder: Öykü kurgusu gibi aynı şeyi aynı zamanda söyleme yetisi olmadığından, onun benzeri olarak rastlantısal ve yanlış bir yerde söylemekte, anlatının ardışık sürecini sabote etmektedir (Jefferson, 1983: s.197).

Klasik anlatıyla ilişkilendirilebilecek bir yoruma göre mise en abyme anlatıya karşıt bir yöntemdir. Sadece genel kurgunun yoğunlaştırılmış bir görüntüsü ve bir anlatının teması olarak olumlu işleve sahip olabilir. Hermeneutik bir araç olarak, anlatının ortaya çıkmasına değil; eleştirel analizine katkıda bulunmaktadır (Jefferson, 1983: s.196). Klasik anlatıda kendisini görsel-algısal düzeye yerleştiren kişi, benzer şekilde algısal temelsizlik ve bir çeşit ontolojik vertigo oluşturarak kafa karıştırıcı bir faktör olabilir (Elsaesser, 2018: s.23).

Bu görüşler klasik anlatı özelinde değerlendirildiğinde mise en abyme anlatının bir yardımcısı değil biçimsel düzeyde anlatının kendisi olabilir. Filmin anlatısına katkısı olmaz, yorumlanmasına katkısı olabilir sonucuna varmak mümkündür.

\section{Christopher Nolan ve Sinema Biçemi}

Yönetmen ve senarist Christopher Edward Nolan, 30 Temmuz 1970 tarihinde Londra'da doğmuştur. University College London'da İngiliz edebiyatı öğrenimi görmüştür. Birçok filminde öykü anlatımı için doğrusal olmayan zaman çizgisini kullanmayı tercih etmiştir (Biography.com, 2014).

İlk uzun metrajı filmi Following (Takip, 1998) ile uluslararası film festivallerinde beğeni 
kazanmıştır. Yönetmenliğini ve senaristliğini yaptığı kara film ile daha sonra yapacağı filmler için kendini ispatlamıştır (Sullivan, 2019).

Nolan'ın ikinci filmi Memento (Akıl Defteri, 2000) yakın geçmişin en konformist ve en yeni ve en farklı filmlerinden birisi olarak nitelenmiştir (Bordwell, 2016: s.148). Kardeşi Jonathan Nolan'ın kısa öyküsünden uyarladığı gerilim filmi ile "En İyi Senaryo" ve "En İyi Kurgu" dallarında Oscar adayı olmuş, farklı ödül organizasyonlarında en iyi senaryo, en iyi kurgu, en iyi film ve en iyi yönetmen gibi alanlarda teknik ve sinematografik ödüller kazanmıştır (Internet Movie Database, 2019). Nolan filmde pek çok klasik anlatı aygıtı kullanmıştır. Kahramanı Leonard'ın hastalığını vurgulayabilmek için filmlerinin tekrar ve ikili zaman çizgisi gibi filmi sıradışı kılan klasik anlatı öğelerine kendi yorumunu getirmiştir (Bordwell, 2016: s.149). Film, anlatıyı tersine çeviren bir yapımdır. İzleyicisini, yaygın kullanılan bir anlatı tekniği olan olaylar arasındaki ilişkilere dayalı bir bulmacayı çözmeye odaklamıştır (Edgar-Hunt vd, 2012: s.47).

Insomnia (Uykusuz, 2002) isimli filmi, Christopher Nolan'ın bakışıyla zamanı yorumladığı bir polisiyedir. Filminde izleyiciyi bu kez polisiye bir anlatıda zaman bağlamlı bir bulmacayı çözmeye yönlendirmiştir. Bu kez öyküsü yirmi gün boyunca güneşin batmadığı bir Alaska kasabasında geçmektedir. (Azevedo, 2017)

Nolan'ın yeniden sinemaya uyarladığı Batman karakteri bu kez kendisinden önce yapılan uyarlamaların ardından süper kahramana yeni bir bakış getirmiştir. Batman Begins (Batman Başlıyor, 2005), The Dark Knight (Kara Şövalye, 2008) ve The Dark Knight Rises (Kara Şövalye Yükseliyor, 2012), ilk filmde diğer Batman filmlerinde detaylandırılmayan Bruce Wayne'in süper kahramana dönüşme aşaması anlatılmıştır. Nolan birçok eleştirmene göre filmlerde Batman'i sıradan bir insan haline getirmiş, Joker'i (Heath Ledger) ön plana çıkarmıştır. Batman Başlıyor (2005), bir derinliğe ve kendine has bir tınıya sahip olduğu yönünde değerlendirilmiştir (Newman, 2014: s.532).

Yönetmenin Prestige (Prestij, 2006), Inception (Başlangıç, 2010) ve Interstellar (Yıldızlararası, 2014) zaman kavramını yorumlayan bilim kurgu türündeki filmler olarak dikkat çekmiştir. Zamanın göreliliği ve alternatif gerçeklik Nolan'ın üzerinde durduğu kavramlardır. Filmlerde, karmaşık zaman teorilerine ilişkin öyküleri kendine özgü kurgu anlayışı ile aktarmıştır. Inception (Başlangıç, 2010) filmi "En İyi Sinematografi", "En İyi Ses Kurgusu", "En İyi Ses Miksi" ve "En İyi Görsel Efekt" dallarında Oscar Ödülü almıştır. Yönetmen Nolan ise; Writers Guild of America (Amerikan Yazarlar Birliği, W.G.A) ödülünü almıştır (Sullivan, 2019).

Nolan, 2017 yılında senaristliğini de yaptığı Dunkirk (2017) isimli epik II. Dünya Savaşı filmini yönetmiştir. Bu filmde, 1940 yılında yaşanan olayların dramatik dönüşümünü üç farklı öykü çizgisi ile farklı bakış açılarından aktarmıştır (Biography.com, 2014). Film, "En İyi Kurgu", "En İyi Ses Kurgusu" ve "En İyi Ses Miksi" dallarında Oscar Ödülü almıştır. Christopher Nolan da aralarında en iyi yönetmen, en iyi film olmak üzere farklı dallarda çeşitli ödüllere aday olmuş ve kazanmıştır.

Nolan, Zack Snyder'ın yönettiği Man of Steel (Çelik adam, 2013) isimli filmin yapımcılığını ve senaristliğini üstlenmiştir (Internet Movie Database, 2019). Süper- 
man isimli kahramanın yeniden yorumlanması bağlamında Çelik Adam'ın da Nolan çizgisinde ilerlediğini söylemek mümkündür.

Christopher Nolan zamanın göreliliğinden her zaman etkilendiğini belirten, filmlerinin kurgusunda, senaryosunda ve oluşturduğu anlatı yapısında bu kavramı işleyen bir yönetmen olarak klasik anlatı ürünleriyle ilgi uyandırmıştır (Azevedo, 2017). Nolan'ın filmlerinin önemli bir bölümünde senaryoya katkıda bulunmasını, olay örgüsü, sebepsonuç ilişkileri ve zaman kavramlarını anlatısında uygun biçimde yorumlamasını, klasik anlatı konusunda edebi yeteneklerinin katkısıyla ustalaştığı biçiminde yorumlamak mümkündür. Christopher Nolan edebi metinlerde dikkat çeken zamanın göreliliği kavramını görseller, ses ve görüntü kurgusu, efektler gibi anlatı sinemasının sinematografik öğeleriyle görselleştirmektedir. Filmlerinde anlatı sinemasının temel özelliklerini kullanmaktadır. Ancak, ele aldığı zaman konusunun göreliliği ve belirsizliğini ortaya koyabilmek için filmlerinin zaman çizgisini ve kurgusal yapısını değiştirmektedir. Oluşturduğu biçim filmlerinin özgün yapısının kaynağıdır.

\section{Bașlangıç Filminin Analizi}

Yönetmenliğini Christopher Nolan'ın yaptığı Inception (Başlangıç, 2010) filmi, yönetmenin klasik anlatı sinemasına yaklaşım biçimi konusunda ipuçları verebilecek niteliktedir. Nolan, sinemada zaman kavramı konusundaki tutkusunu süreklilikle dile getiren bir yönetmendir (Azevedo, 2017). Zamanın göreliliği ve bunun klasik anlatı sinemasında görselleştirilmesi konusunda Başlangıç dışında da filmleri bulunmaktadır. Başlangıç filminin bu filmler arasında dikkate değer olan özelliği, yönetmenin filminin senaryosunu kendisi yazmış olmasıdır. Başlangıç, yönetmenin en yüksek getiri sağlayan filmlerinden birisidir. Anlatı sineması ürünlerinin izler kitle tarafından anlaşımasının ve beğenilmesinin bu alanda yapılan çalışmalar açısından bir veri olduğunu söylemek mümkündür. Zamanın göreliliği gibi soyut bir kavramın klasik anlatı sinemasının ilkeleri bağlamında sunumu, Nolan'ın sinema anlayışı yanında; klasik anlatı sinemasının farklı ve zor anlaşıır film yapıları altında varlığını sürdürmesinin de bir göstergesidir. Filmin sinematografi, ses miksi, ses kurgusu ve görsel efektler gibi dallarda ödüller alması klasik anlatı sinemasının mesajını verme biçimiyle örtüşmektedir. Teknolojinin, sinematografinin ve anlatı sinemasının tüm özelliklerinin kullanılarak öykü anlatılması, Hollywood film sektörünün temel amacıdır. Nolan'ın bu bakış açısına kaynaklık eden alanlarda ve onun kalıplarını yeniden tanımlayarak başarı kazanması Başlangıç filminin analiz edilmesinin önemini ortaya koymaktadır.

Başlangıç filmi, yetenekli bir hırsız olan Dom Cobb'un öyküsüdür. Cobb insanların zihinlerindeki sırların çalınması konusunda uzmanlaşmıştır. İnsan zihninin savunmasız olduğu rüya anında hedefinin bilinçaltına sızarak sırlarını çalmaktadır. Yaptığı bilinçaltı sızmalar genellikle şirketler arası casusluklar kapsamındadır. Son işinde Saito'nun (Ken Watanebe) zihninden şirket sırlarını çalmaya çalışırken yakalanır. Saito onları yakalatmamasının karşılığında yeni bir iş önerir. Dünyanın en büyük enerji şirketinin veliahtı Robert Fischer'ın (Cillian Murphy) zihnine, babası Maurice Fischer'ın ölümüyle devralacağı şirketi bölme fikrini yerleştirmek zorundadır. Cobb'un uzmanlık alanı düşünce çalmaktır. Ancak bu kez bilinçaltına düşünce yerleştirmek zorundadır. Görev 
konusunda şüpheleri olsa da ülkesine dönebilmek için görevi üstlenmek zorundadır. Rüyalarla bilinçaltına sızmak konusunda yaptığı çalışmalarda zihnine sızdığı kişilere rüyaları içinde rüya gördürerek bilinçaltının daha da derinlerine inilmesi konusunda eşi Mal (Marion Cotillard) ile çalışmıştır. Eşi rüya ile gerçeği ayırt etme yetisini kaybettiğinde, rüyadan kurtulmak Cobb’a da kendisini öldürmesini tavsiye etmiştir. Böylece gerçek dünyada uyanacaklardır. Oysa, gerçek dünyadadırlar; Cobb Mal'ı ikna edemediği için eşi kendisini öldürür. Bıraktığı mektupta Cobb’u suçladığından Cobb Amerika'ya girememekte çocuklarını görememektedir. Saito için Cobb'un geçmişini temizlemek mümkündür. Cobb'un Robert Fisher'ın zihnine şirketini bölme fikrini sokması yeterlidir. Mal, bir bakıma Başlangıç filminde Cobb'un girdiği tüm maceraların nedenidir. Campbell'ın Kahramanın Sonsuz Yolculuğ isimli eserinde vurguladığı "Aşık olarak Kahraman"ın Cobb olduğunu söylemek mümkündür. Mal'ın ölümünü engellerse ülkesine girip çocuklarına kavuşabilecek, bir anlamda özgürlüğünü kazanacaktır. Kendisinin suçsuzluğunu kanıtlaması eşini kurtarmasına bağlıdır. Bu anlamda, Mal Campbel'ın belirttiği canavarın kötülüğünden kurtularak kazanılmış özgürlük, yaşam enerjisi ve kahramanın diğer yarısıdır (Campbell, 2015: s. 301).

Cobb'un başka çaresi olmadığından yeni işi için ekibini oluşturmaya başlar. Mimar Ariadne'yi (Ellen Page) rüya evrenini tasarlaması için, Yusuf'u (Dileep Rao) ise kendilerini rüya görmeye yönlendirecek sakinleştiriciyi üretmesi için ekibine katar. Bu kez, fikir çalmak değil zihne fikir ekmek için çalışacağından sakinleştiriciler daha güçlü olmalıdır ve bilinçaltının üç seviye derinine inilmelidir.

Robert Fisher'ın zihni bu tip ihtimallere karşı eğitimlidir. Her seviyede koruma amaçlı eğitimli bilinçaltı imgeleri ile korunmaktadır. Fisher'ın vaftiz babası Peter Browning (Tom Berrenger) de şirketi kontrol ettiği için diğer bir engeldir. Robert'a amcasından şüphe etmesi ve babasının aslında kendisinin şirketi bölmesini istediği fikrinin benimsetilmesi gerekmektedir. Tüm bunlar yapılırken Cobb'un en kuvvetli engelleyicilerinden birisi de eşi Mal'ın imgesidir. Sonuçta, görev başarıldığı için Saito yetkilileri arar ve Cobb ile ilgili suçlamaları düşürür. Cobb çocuklarına kavuşur. Bu sırada rüyada olup olmadığını anlamak için totemi olan topacı çevirir. Yönetmen ekranı karartır. İzleyici Cobb'un rüyada olup olmadığını öğrenemez. Cobb da önemsememiştir. Sonuçta, çocukları ile birliktedir. Gerçeklik görelidir ve tercih ettiğimizi yaşarız mesajı iletilmiştir.

Film, klasik anlatı sinemasının diğer örneklerinde de görüldüğü üzere ana öykü ve yan öykülerden oluşmaktadır. Filmin ana öyküsü, Cobb'un çocuklarını tekrar görebilmek için Saito'un isteği üzerine Robert Fisher'ın zihnine şirketini bölme fikrini yerleştirme çabasıdır. Cobb'un eşi Mal'ın ölümünden duyduğu suçluluk duygusundan sıyrılma çabası ana öyküye bağlı bir yan öyküdür. Cobb ve ekibinin amaçlarına ulaştırmak için girdikleri her rüya katmanını birer yan öykü olarak düşünmek mümkündür. Bu öykülerde; Robert Fisher'ın babasının izinden gitmeyi reddetmesi; kendim bir şeyler yapmalıyım demesi ve babam onun gibi olmamı istemedi demesi hedeflenmiştir.

Başlangıç, karmaşık gözüken öyküsü hakkında ciddi bir serim bölümüyle başlamaktadır. Filmin ilk yirmi dakikasında Cobb ve ekibi Saito'dan yeni görevlerini alır. Bu dakikadan sonra izleyiciye yaklaşık kırk dakika boyunca Cobb'un çocuklarını görme amacı ve eşi Mal'ın bilinçaltında yaşaması anlatılır. Yusuf, Ariadne ve Eames (Tom Hardy) 
ekibe dahil edilirken bilinçaltında üç seviye ilerleneceği için daha güçlü yatıştırıcılar yapılması gereği, labirente benzer bilinçaltı mekanları yaratılarak birbirine bağlanması ve Fischer'ı etkileyecek kurgunun oluşturulması için kendisiyle ilgili daha fazla bilgi edinilmesi gereği izleyiciye anlatılmaktadır.

Christoher Nolan, oluşturduğu karmaşık zaman bulmacasının çözümünü izleyiciye anlatmaktadır. İlk bilinçaltı katmana girilmesi için on saat sürecek Sidney, Los Angeles uçuşu belirlenir. Girilen ilk rüya katmanında, Cobb ve ekibi Robert'ı kaçırır. Babası ile ilişkisi hakkında detaylı bilgi edinir. Zihnine babasının gizli vasiyeti ver bulunduğu kasa ile ilgili düşünceyi yerleştirir. Bu sırada Saito vurulur.

İkinci rüya katmanında, otelde Robert Cobb tarafından kendisine yardımcı olmaya çalıştığına ikna edilir. Robert'ın vaftiz babası Peter ile ilgili üphe zihnine yerleştirilir. Buna göre; Peter Robert'ın babasının istediği gibi şirketini bölmesini engellemeye çalışmaktadır. Bu nedenle kendisini kaçırtmıştır. Böylece şirketi böldürmeyecektir. Robert, Peter'ın gerçek isteklerini öğrenmek için Cobb ile anlaşarak zihnine girmeyi kabul eder.

Üçüncü katmanda, kale benzeri modern bir yapıda Peter babası ile görüşmeden önce Mal tarafından öldürülür. Görevin başarısızlıkla sonuçlanmaması için Ariadne, Cobb ile araf denilen işlenmemiş bilinçaltı katmanında Mal ve Robert'ı bulurlar. Bu katmanda Ariadne Robert'ı üst katmana göndermek için öldürür. Mal'ı da vurur. Böylece Cobb'un bilinçaltındaki suçluluğu biter. Cobb bu katta kalarak bir üst katmanda ölen Saito'yu bulur ve anlaşmalarını hatırlamasını ister.

Başlangıç filmi, bilinçaltı ve zaman gibi somut kavramları açıklayabilmek için sinematografik araçlar yanında klasik anlatıya ilişkin araçlardan da yararlanmıştır. Nolan'ın kurguladığı rüya içinde rüya yapısı da film içerisinde rüya ortamı için mimari tasarım yapmayı öğrenme aşamasında Ariadne tarafından izleyiciye anlatılmıştır. Ariadne, Cobb'dan ne yaptıklarını öğrenirken üst geçide karşılıklı iki ayna yerleştirir. İç içe geçen sonsuz yansımalar "mise en abyme" kavramının en yalın ifadesidir. Klasik anlatı sinemasında kullanılan bir tekniktir. Pek çok farklı tanımı olmasına karşın filmde, birbirine bağlı iç içe öyküler anlamında kullanılmıştır. Christopher Nolan'ın senaryosu bağlamında "mise en abyme" kavramı ile ilgili en önemli yaklaşım farkı; öykünün akışını bozan bir kavram olarak değil anlatıyı destekleyen ve onu ilerleten bir kavram olarak kullanılabilmesidir. Başlangıç filminin kendisi de bir "mise en abyme"dir. Çünkü film kurgusal yapısı içinde kurgusal evrenler oluşturmayı anlatmaktadır.

Filmde, ayna objesi Lacan psikolojisi bağlamında da kullanılmıştır. Eames, bilinçaltında oldukları kişileri etkileyebilmek için onların tanıdıkları kişilerin kılığına girmektedir. Asıl kimliği ise sadece aynaya baktığında görülebilmektedir. Lacan, "bilinçaltı bir dil gibi yapılandırılır (Stam, 2014, s. 172)" sözleriyle bireylerin bilinç gibi bilinçaltı düzeyde de yönlendirilebileceğine vurgu yapmıştır. Nolan da Başlangıç filmi boyunca bu fikir bağlamında ilerlemiştir.

Christopher Nolan'ın soyut bilinçaltı evrenini görselleştirebilmek için kullandığı önemli araçlardan birisi görsel efektlerdir. Bilinçaltı seviyelerinin birbiriyle ilişkili olduğunu izleyiciye anlatabilmek için paralel kurgu yanında uzam bağı da kurmak istemiştir. 
Örneğin köprüden düşmekte olan minibüsün içindeki ekip üyelerinin yaşadığı fiziki koşullar otel seviyesinde de uçan ekip üyeleri olarak özel efektlerle görselleştirilmiştir. Otelde olan patlama arafta yıkılan binalar olarak görselleştirilmiştir. Zamanın göreliliği kavramının açıklanması için minibüsün düşüş anı ağır çekimde gösterilmiş. Paralel kurgu ile sürekli olarak otele geçişler yapılmıştır. Otel sahneleri ise gerçek zamanlı görüntülenmiştir.

Ses efektleri ve non diegetik müzikler de zaman-uzam algısı ve zamanın göreliliğini vurgulamak için kullanılmıştır. Edith Piaf'ın "non je ne regrette rien" (pişman değilim) isimli şarkısı diegetik olarak gerçek zamanlı ve yavaşlatılmış olarak kullanılmışır. Ağır çekimli sahnelerde müzik de yavaşlatılmış böylece zamanın görece olarak yavaş ilerlediği fikri görselleştirilmiştir.

Pişman değilim şarkısı leitmotif olarak da kullanılmıştır. Ekip üyelerine seviyeler arasında geçiş için bir sinyal müziğidir. İzleyici bu şarkıyı duyduğunda bilinçaltı seviyeleri arasında geçiş olacak bir "dürtme" olduğunu anlamaktadır. Şarkının bir diğer özelliği de metinsel düzeyde Cobb’un durumuna dikkat çekmektedir. Piaf şarkısında geçmişten pişmanlık duymadığını ve unuttuğunu anlatmaktadır. Mal'u geçmişte bırakması ve hiçbirşeyden pişmanlık duymaması gereğine vurgu yapmaktadır.

\section{Bulgular}

Christopher Nolan'ın filminde kullandığı sinematografik aygıtlar olan müzik, özel efektler ve kurgu klasik anlatı sinemasının öyküsünü görselleştirmek için geleneksel olarak kullandığı araçlardır. Ayna imgesi ve mise en abyme gibi psikolojik ve edebi yaklaşımlar ise Nolan gibi edebiyat öğrenimi görmüş bir senarist için kaçınılmaz olarak hayata geçirilmesi gereken anlatıyı boyutlandıran araçlardır. Nolan, edebiyat ve felsefe alanında kullanılan kavramları Başlangıç filminde klasik anlatı sinemasına uyarlamıştır.

Filmin anlatı yapısının metin düzeyinde analiz edilmesi kapsamında Todorov'un Aristoteles'in anlayışına dayandırdığı üç unsura bakılacak olursa;

Denge durumu; Cobb'un ekibiyle yaptığı sanayi casusluklarıyla süren hayatıdır. Hedeflerindeki kişilerinin uykularında rüyalarına girmekte, bilinçaltlarına inmekte ve şirketlerine iliş̧in sırlarını çalmaktadırlar.

Dengenin bir olay nedeniyle bozulması; Seito'ya yakalanmalarıdır. Bu dönüm noktasında, artık onun isteklerini yerine getirmek dışında yapabilecekleri bir şey bulunmamaktadır. Özellikle çocuklarını görmek isteyen Cobb için bu kaçınılmazdır.

Dengenin yeniden sağlanmasına yönelik başarılı çaba ise Başlangıç filmindeki üç aşamalı plandır. Robert filmin sonunda şirketlerini bölmeye karar vermiştir. Ancak, Cobb’un çocuklarını gördüğü anın gerçek ya da rüya olup olmadığı bilinmemektedir. Ancak, yönetmenin filmlerinde sıklıkla ele aldığı gerçekliğin sübjektifliği ve zamanın göreliliği kavramları düşünüldüğünde Cobb'un başarıya ulaştığını söylemek mümkündür. Çünkü totemine bakmamış tercih ettiği gerçeklikte yaşadığını göstermiştir.

Filmde, karakterler dengenin bozulduğunu tespit ederler. Başlangıç filminde her aşamada denge Cobb ve ekip elemanları tarafından kontrol edilir. 
Cobb'un ekibi, Saito tarafından yakalandıklarında onun dediklerini yapmaları gerektiğini anlarlar. Cobb, her bilinçaltı düzeyinde ne yapacaklarını yeniden planlar ve ekibe uygulatır. Edindikleri bilgilere göre yeni aşamadaki planlarını şekillendirirler. Son aşamada Ariadne, Robert öldüğü anda başarısız olabileceklerini anlar ve yeni bir planla arafa inmeleri gerektiğini söyler.

Todorov'un belirlediği unsurlara göre; Christoher Nolan klasik anlatı sinemasının benimsediği ilkeleri Başlangıç filminde uygulamıştır.

Başlangıç filminin Genette'nin önerdiği kavramlar ışığında değerlendirilmesinde ise; Filmin hikâyesi bağlamında, basit ve her aşamasında izleyicinin bilgilendirildiği bir yapısı olduğunu söylemek mümkündür. Bununla birlikte, öykünün doğasından kaynaklanan olguların aktarılabilmesi için öykü içinde öyküler anlatılmış ve bunlar paralel kurgu tekniği ile birbirine bağlanmıştır. Hikâye zamanın göreliliği ilkesine dayalı olarak doğrusal bir biçimde anlatılmıştır. Ancak, özellikle Cobb’un Mal ile olan ilişkisi ile ilgili olarak flashbacklere yer verilmiştir. Hikayedeki olaylar farklı bilinç düzeylerinde olsalar da nedensellik bağlamında aktarılmıştır. Yuvarlanan minibüsün ortamının yansıması olarak diğer bilinç düzeyinde de karakterler duvarlarda yürüyebilmektedir. Karakterler ve öykü dengesi düşünüldüğünde Başlangıç filminde bilimkurgu türünün diğer örneklerinde yaygın olduğu üzere detaylı karakter betimlemeleri yerine öykü odaklı olarak karakterler hakkında bilgi verildiği gözlemlenmiştir. Hikâyenin temel odağı zaman ve uzamdır. Filmin farklı bilinçaltı düzeylerinde ilerlediğinin belirtilmesi için ana zaman çizgisine bağı ıarklı zaman boyutları kurgulanmıştır. Her boyut için mekânsal tasarımlar yapılmıştır.

Filmde, yapılan iş fikir hırsızlığı ya da zihne fikir yerleştirmedir. Bu anlamda, karakterlerin yaptıkları işlerle ilgili olarak ahlaki bir sorgulama olumsuz sonuçlanabilecektir. Karakterlerin kendi aralarında oluşturdukları ilişkiler ise güven ve sadakat prensiplerine dayanmaktadır. Bu anlamda, zaman boyutuyla göreliliği anlatan öykü ana karakterleri boyutuyla da etik değerlerin göreliliğini gözler önüne sermektedir.

Filmde ses ve müzik anlatıyı destekleyici öğeler olarak kullanılmıştır. Müziğin diegetik kullanımı leitmotif bağlamında öykü izleği hakkında bilgi vermektedir. Non diegetik müzik kullanımı ise diğer efektler gibi öykünün atmosfer ve psikolojisi hakkında bilgi vermektedir. Filmdeki diyaloglar, anlatıyı geliştirme ve izleyiciyi bilgilendirme bağlamında klasik anlatı öğeleri olarak kullanıımıştır.

Başlangıç filmi metin boyutuyla incelendiğinde; Nolan'ın diğer filmlerinde karakteristik olarak görüldüğü üzere tekrarların yaygın biçimde kullanıldığı görülmektedir. Klasik anlatının tekniklerinden olan tekrar Cobb'un çocuklarına kavuşma isteği, Mal'un ölümü ile ilgili suçluluğu ve bilinçaltına inişlerde yapılması ve yapılmaması gerekenler bağlamında sıkça başvurulan bir tekniktir. Robert Fischer ve şirketi ile ilgili planlar izleyiciye tekrarlarla anlatılmaktadır. Karakterlerin kostümleri bulundukları bilinçaltı düzeyine göre değişiklik göstermekte böylece zaman uzam ilişkisinin kurulması kolaylaştırılmaktadır. Karakterler farklı sosyal ve kültürel özellikler göstermektedir. Başlangıç filminde ana karakter Cobb'dur. Ancak, film boyunca Ariadne, Arthur (Joseph Gordon-Levitt) ve Eames uzmanlık alanları ile ilgili olarak bilgi vermektedir. Cob dışında olayları yönlendiren ikinci en güçlü karakter Ariadne'dir. Robert'ın ölümü 
ardından görevi başarıya ulaştıran fikri önermiş ve uygulama kararlılığını göstermiştir.

\section{Sonuc}

Christopher Nolan, filmlerinde zaman - uzam algısına getirdiğini yorumla ve kurgu biçimiyle zamanın göreliliği kavramını ele aldığı filmlere imza atmıştır. Edebiyat öğrenimi görmüş bir yönetmendir. Filmlerinin önemli bir bölümünde senaryo da kendisine aittir. Bu özellikler auteur yönetmenlerin karakteristiklerine uymaktadır. Kökenleri Aristoteles'in Poetikası'na dayanan klasik anlatı sineması, olay örgüsü, nedensellik, özdeşleşme ve katharsis gibi kavramlar ışığında film üretilmesine dayalıdır.

Nolan'ın filmleri özgün nitelikler taşısa da klasik anlatı ürünleri olma özelliklerini sürdürmektedir. Yönetmenin başarısı bu ilkeleri yorumlama biçiminden kaynaklanmaktadır. Özellikle, Başlangıç filminin temasında görülen zamanın göreliliği ve bilinçaltı gibi soyut kavramları görselleştirmede klasik anlatı sinemasının teknik ve anlatı özelliklerini kullanmıştır. Yönetmenin filminde kuvvetli nedensellik bağları dikkat çekicidir. Diğer filmlerinde olduğu gibi Başlangıç’ta da öyküsünü kurabilmek için tekrarlara başvurmuştur. Anlatısını geliştirebilmek için flashbackleri kullanmıştır. Birçok filminde olduğu gibi paralel kesmeleri öyküsünü kurgulamak için kullanmıştır. Başlangıç filminde paralel kesmeler zaman yanında mekânsal birliğin de kurulmasına hizmet etmektedir. Bunu yaparken klasik anlatı sinemasının en önemli araçlarından olan görsel efektler ve ses yönetmen tarafından kullanılmıştır.

Nolan filmlerinde öyküler genel anlamda kısıtlı sürelerde tamamlanmak durumundadır. Başlangıç filminde klasik anlatının bu tipik özelliği öykü boyutları arasında bağlantı kurulması için kullanılmıştır. Filmin Todorov ve Genette'nin ilkeleri bağlamında yapılan analizi de Christopher Nolan'ın klasik anlatı sineması geleneğini sürdürdüğünü ortaya koymaktadır. Filmin öyküsünün bölümlenmesi, zaman ve uzam seçimi bu düşünceyi doğrular niteliktedir. Başlangıç filmi edebiyat alanında ortaya çıkış olan mise en abyme yönteminin bir uyarlaması niteliğindedir. Filmin pek çok yerinde kahramanların dillendirdiği rüya içinde rüya kavramı dışında filmin kendisi de kurgusal bir evren içerisinde yeni kurgusal evrenler oluşturulmasını anlattığından mise en abyme örneğidir. Filmde kullanılan ayna metaforu mise en abyme yanında bilinçaltının şekillendirilebileceğini savunan Lacan'ın psikoloji anlayışına da gönderme olarak nitelenmiştir.

Christoher Nolan, filmlerinin özgün yapısıyla, klasik Hollywood anlatısı geleneğini yorumlayan bir yönetmendir. Başlangıç filminde, eserlerinin genelinde görüldüğü üzere edebiyat tekniklerini yorumlamış, psikoloji ve fizik alanındaki soyut kavramları görselleştirmiştir. Senaryo yapısı ve sinematografisi ile klasik anlatı sineması geleneğini sürdürmektedir.

\section{Kaynakça}

Aristoteles. (1987). Poetika. İ. Tunalı (Çev.), İstanbul: Remzi Kitabevi. 
Armes, R. (2019). Sinema ve Gerçeklik. Z. Ö. Barkot (Çev.) İstanbul: Doruk Yayımcılık. Azevedo, L. (Yazar), ve Azevedo, L. (Yöneten). (2017). Christopher Nolan's Time Puzzle [Video] 18 Ağustos 2019 tarihinde https://www.youtube.com/watch?v=blqE6oCooDs adresinden edinildi.

Barnwell, J. (2015). Film Yapımının Temellleri. G. Altıntaş (Çev.) İstanbul: Literatür Yayınları. Bazin, A. (2011). Sinema Nedir? İ. Şener (Çev.) İstanbul: Doruk Yayınları.

Biography.com. (2014). Christopher Nolan Biography. (A\&E Television Networks) 18 Ağustos 2019 tarihinde The Biography.com: https://www.biography.com/filmmaker/christopher-nolan adresinden edinilmiştir.

Biro, Y. (2011). Sinemada Zaman. A. C. Altunkanat (Çev.) İstanbul: Doruk Yayımcılık.

Bordwell, D. (2016). Hollywood'un Film Dili. Z. Atam, Y. C. Ekinci, ve B. Tanyeri (Çev.) İstanbul: Doruk Yayımcilık.

Bordwell, D. ve Thompson, K. (2008). Film Art An Introduction. New York: McGraw-Hill.

Brown, B. (2014). Sinematografi "Kuram Ve Uygulama”. S. Taylaner (Çev.) İstanbul: Hil Yayın.

Buckland, W. (2018). Sinemayı Anlamak. T. Göbekçin (Çev.) İstanbul: Hayalperest Yayınevi.

Büker, S. (2011). Sinemada Anlam Yaratma. İstanbul: Hayalperest Yayınevi.

Campbell, J. (2017). Kahramanın Sonsuz Yolculuğu. (S. Gürses, Çev.) İstanbul: İthaki.

Çakır, D. S. (2019). Ümit Ünal Filmlerinde Özdüşünümsellik. Yayımlanmamış Yükseklisans Tezi. Ankara: Hacettepe Üniversitesi Sosyal Bilimler Enstitüsü.

Edgar-Hunt, R., Marland, J. ve Rawle, S. (2012). Film Dili. S. Aytaç (Çev.) İstanbul: Literatür.

Elsaesser, T. (2018). Contingency, Causality, Complexity: Distributed Agency in the Mind-game film. New Review of Film and Television Studies, 16(1): s.1-39.

Erdoğan, i. (2003). Pozitivist Metodoloji. Ankara: Erk.

Ersümer, A. O. (2013). Klasik Anlatı Sineması. İstanbul: Hayalperest Yayınevi.

Foss, B. (2016). Sinema ve Televizyonda Anlatım Teknikleri ve Dramaturji. M. K. Gerçeker, (Çev.) İstanbul: Hayalperest Yayınevi.

Gianetti, L. (2001). Understanding Movies. New Jersey: Prentice Hall.

Nolan, C. (Yönetmen). (2010). Inception [Film]. Amerika Birleşik Devletleri: Warner Bros.

Ulutaş, S. (2017). Sinema Estetiği. İstanbul: Hayalperest Yayınevi.

Ünal, Ü. (2015). Sinemanın Dili. A. O. Ersümer (ed.). Sinema Neyi Anlatır. İstanbul: Hayalperest Yayınevi, s.11-18

Ünal, Y. (2015). Dram Sanatı ve Sinema Klasik Anlatı Yapısının Kökenleri. İstanbul: Hayalperest Yayınevi.

Internet Movie Database. (2019). Çelik Adam Full Cast\&Crew. (imdb.com) 18 Ağustos 2019 tarihinde imdb.com: https://www.imdb.com/title/tt0770828/fullcredits?ref_=tt_ov_wr\#writers/ adresinden edinilmiştir.

Internet Movie Database. (2019). Awards. (IMDB) 16 Ağustos 2019 tarihinde Internet Movie 
Database (IMDB): https://www.imdb.com/title/tt0209144/awards?ref_=tt_awd adresinden edinilmiştir.

Jefferson, A. (1983). "Mise en abyme" and the Prophetic in Narrative. Style, 17(2): s.196-208.

Larsson, D. F. (2014). Narrative. (Oxford University Press) 12 Ağustos 2019 tarihinde Oxford Bibliographies: https://www.oxfordbibliographies.com/view/document/obo-9780199791286/ obo-9780199791286-0119.xml?rskey=rTwzzU\&result=2\&q=hollywood+narrative\#firstMatch adresinden edinildi.

Lawlor, P. (1985). Lautréamont, Modernism, and the Function of Mise en Abyme. The French Review, 58(6): s.827-834.

Makal, O. (2009). Sinemada Tarihin Etki Alanı. Beykent Üniversitesi Sosyal Bilimler Dergisi, 3(1), 132-158.

Makal, O. (2014). Sinemada Tarihin Görüntüsü. İstanbul: Kalkedon Yayıncılık.

Meritt, R. (2011). D.W. Griffith. (Oxford University Press) 8 Ağustos 2019 tarihinde Oxford Bibliographies: https://www.oxfordbibliographies.com/view/document/obo-9780199791286/obo9780199791286-0022.xml?rskey=mmMJOP\&result=1\&q=Wark+Griffith\#firstMatch adresinden edinildi.

Metz, C. (2012). Sinemada Anlam Üstne Denemeler. O. Adanır (Çev.) İstanbul: Hayalperest Yayınevi.

Miller, W. (2016). Senaryo Yazımı. Y. Büyükerşen, Y. Demir ve N. Esen (Çev.) İstanbul: Hayalperest Yayınevi.

Mükerrem, Z. (2012). Sinematografi Üzerine Düşünceler "Kuram ve Uygulamalar". İstanbul: Ayrıntı Yayınları.

Myers, S. (2017). Christopher Nolan on the Story and Structure of "Memento". (Medium) 15 Ağustos 2019 tarihinde Medium.com: https://gointothestory.blcklst.com/christopher-nolan-onthe-story-and-structure-of-memento-13b0b21271d4 adresinden edinildi.

Neumeyer, D. (2011). Music and Cinema, Classical Hollywood. (Oxford University Press) 8 Ağustos 2019 tarihinde Oxford Bibliographies: https://www.oxfordbibliographies.com/view/ document/obo-9780199791286/obo-9780199791286-0118.xml?rskey=rTwzzU\&result=4\&q=holl ywood+narrative\#firstMatch adresinden edinildi.

Newman, K. (2014). Batman Başlıyor 2005. P. Kemp (ed.). Sinemanın Tüm Öyküsü E. YıImaz ve N. Yılmaz (Çev.), (s. 532-533). İstanbul: Hayalperest Yayınevi.

Özkan, B., ve Gündoğdu, A. E. (2012, Mayıs-Haziran). Müzik Kliplerinde Anlatı Çözümlemesi: "Kadıköy" Örneği. Akademik Bakış Dergisi(30), 1-14.

Özön, N. (2008). Sinema Sanatına Giriş. İstanbul: Agora Kitaplığı.

Snow, M. (2016). Into the Abyss: A Study of the mise en abyme. London Metropolitan University. Stam, R. (2014). Sinema Teorisine Giriş. S. Salman ve Ç. Asatekin (Çev.) İstanbul: Ayrıntı Yayınları.

Sullivan, S. (2019). Christoher Nolan Biography. (imdb.com) 16 Ağustos 2019 tarihinde Internet Movie Database (IMDB): https://www.imdb.com/name/nm0634240/bio?ref_=nm_ov_bio_sm adresinden edinildi.

Toscano, M. (2015). Kuleshov Effect: The Man behind Soviet Montage. 15 Ağustos 2019 tarihinde The Curator Magazine: http://www.curatormagazine.com/michaeltoscano/kuleshovs- 
effect-the-man-behind-soviet-montage/ adresinden edinildi.

Yemenici, A . (1995). Labov'un Anlatı Çözümleme Yöntemi ve Bir Uygulama. Dilbilim Araştırmaları Dergisi , 6 , 39-55 . 20 Aralık 2019 tarihinde http://dad.boun.edu.tr/tr/ issue/4535/313059 adresinden edinildi.

Zeyrek, D . (1991). Göstergebilim, Söylem Çözümlemesi ve Anlatı Incelemesi. Dilbilim Araştırmaları Dergisi , 2, 105-112 . 19 Aralık 2019 tarihinde http://dad.boun.edu.tr/tr/ issue/29237/313016 adresinden edinildi. 